\title{
Antibody response in seropositive multiple sclerosis patients vaccinated with attenuated live varicella zoster virus
}

\author{
RT ROSS CM MD FRCP, MR DAWOOD PhD, MARY CHEANG MMath, LINDSAY E NICOLLE MD FRCPC
}

RT ROSS, MR DAWOOD, M CHEANG, LE NICOLLE. Antibody response in seropositive multiple sclerosis patients vaccinated with attenuated live varicella zoster virus. Can J Infect Dis 1996;7(5):303-306.

OBJECTIVE: To determine the safety and effectiveness of live attenuated varicella zoster virus (VZV) vaccine (OKA/Merck) on 50 patients with chronic progressive multiple sclerosis (MS), based on the hypothesis that VZV might be the antigen or antigen mimic of MS plus the fact that repeated high antigen doses have produced 'antigen paralysis' in experimental allergic encephalomyelitis mice.

DESIGN: Fifty patients were randomly selected without controls. They were assessed clinically at entry and on four other occasions over 14 months. Enhanced cranial magnetic resonance imaging (MRI) was performed at entry and at six and 12 months post entry. All were vaccinated after initial assessment and again six weeks later.

SETTING: All clinical and laboratory assessments were performed at the Health Sciences Centre, Winnipeg, in the outpatient department. All MRI examinations were performed at the St Boniface General Hospital, Winnipeg, Manitoba. Both are tertiary care hospitals.

POPULATION STUDIED: Fifty randomly selected patients with chronic progressive MS, age 18 to 60 years, and a disability status scale of 2.0 or greater were included. Forty-five patients completed the study. INTERVENTIONS: Two vaccinations with attenuated live VZV six weeks apart.

RESULTS: All patients were VZV seropositive at entry and all showed an increased antibody level following vaccination. No one was harmed by the vaccine. There may have been some changes in the MS of 15 patients. CONCLUSIONS: It may be reasonable and safe to challenge the process of MS using large doses of the immunogenic proteins of the VZV to induce 'immune paralysis'.

Key Words: Multiple sclerosis, Serum varicella antibodies, Varicella vaccine

\section{Réponse immunitaire chez des patients atteints de sclérose en plaques séropositifs et vaccinés au moyen du virus vivant atténué Herpesvirus varicellae}

OBJECTIF : Déterminer l'innocuité, l'efficacité d'un vaccin à Herpesvirus varicellae vivant atténué (OKA/Merck) chez 50 patients atteints de sclérose en plaques progressive chronique sur la base de l'hypothèse selon laquelle le virus pourrait être l'antigène ou un antigène imitant la sclérose en plaques en plus du fait que des doses élevées d'antigène à répétition ont produit une paralysie antigénique chez des souris atteintes d'encéphalomyélite allergique.

MODÈLE : Cinquante patients ont été choisis au hasard, sans témoins. Ils ont été évalués sur le plan clinique lors de l'ad-

voir page suivante

Section of Neurology; Biostatistical Consulting Unit Community Health Sciences; Infectious Diseases and Department of Medical Microbiology, University of Manitoba and Health Sciences Centre and Cadham Provincial Laboratory, Winnipeg, Manitoba

Correspondence and reprints: Professor RT Ross, Health Sciences Centre, GF 535 - 820 Sherbrook Street, Winnipeg, Manitoba R3A 1R9. Telephone 204-787-4951, fax 204-787-1486

Received for publication January 18, 1996. Accepted March 29, 1996 
mission et à quatre reprises au cours d'une période de 14 mois. Une imagerie par résonnance magnétique du crâne a été effectuée au départ, puis 6 et 12 mois après leur admission. Ils ont tous été vaccinés après l'évaluation initiale et à nouveau 6 semaines plus tard.

CONTEXTE : Toutes les évaluations cliniques et analyses de laboratoire ont été effectuées au Health Sciences Centre de Winnipeg, au service des consultations externes. Toutes les épreuves d'IRM ont été effectuées à l'Hôpital Général de Saint-Boniface, à Winnipeg, au Manitoba. Il s'agit de deux établissements de soins tertiaires.

POPULATION ÉTUDIÉE : Cinquante patients, choisis au hasard, atteints de sclérose en plaques progressive chronique, âgés de 18 à 60 ans et présentant un statut d'incapacité de 2 ou plus. Quarante-cinq patients ont mené l'étude à terme.

INTERVENTIONS : Deux vaccinations à l'aide d'un vaccin à Herpesvirus varicellae vivant atténué à six semaines d'intervalle.

RÉSULTATS : Tous les patients étaient séropositifs à l'égard du virus au moment de l'admission et ont tous manifesté un taux d'anticorps accru après la vaccination. Le vaccin ne leur a fait aucun tort. Certains changements ont pu affecter la sclérose en plaques chez 15 patients.

CONCLUSIONS : Il serait raisonnable et sûr de déstabiliser le processus de la sclérose en plaques en utilisant de fortes doses des protéines immunogènes de l'Herpesvirus varicellae pour provoquer une «paralysie immunitaire».

$\mathrm{T}$ wo young adults with clinically definite multiple sclerosis (MS) had substantial remissions of the disease after contracting varicella (1). Both had varicella as children. This observation raised questions about a possible relationship between MS and varicella.

MS has a diminishing prevalence gradient north to south in North America (2), and the annual maximum incidence of varicella correlates with this geography (3). In many tropical countries varicella is an adult disease of relatively low contagion (4) and in these countries MS is almost unknown. Conversely, most countries with a varicella incidence of $100 \%$ in children under age nine are high risk for MS. A notable exception is Japan, which has a high incidence of childhood varicella and a low MS prevalence $(5,6)$.

The medical records of a group of 5600 Hutterites living in western Canada were examined for MS, varicella and herpes zoster, and compared with their non-Hutterite neighbours who served as controls. Despite living in an MS high risk area, being of Austrian origin, and having phenotypic markers indicating an increased risk of MS, the Hutterites had significantly less of all three diseases. They used the health care system three times as often as the controls (7).

An additional possible relationship between MS and varicella is suggested by the effect of migration on the subsequent risk of MS. Migration of a family from a low MS risk country (Jamaica) to a high risk country (England) does not change the rate of expected MS among adults. The children, however, particularly the United Kingdom-born children, begin to develop MS at about the same rate as the native British (8). Immigration in the opposite direction (England to South Africa) has no effect on adults but reduces the expected rate of MS in the children $(9,10)$. The precise critical age of migration is unknown but appears to be about 10 to 15 years. By that age virtually $100 \%$ of children from a high MS risk country have had varicella (11).

Furthermore, Critchfield et al (12), using the experimental animal model of MS (experimental allergic encephalomyelitis), have shown that repeated high antigen doses (myelin basic protein) in two in vitro models and in two susceptible mouse strains produced deletion of autoreactive $\mathrm{T}$ cells and diminution of both clinical and pathological manifestations of the disease.

The varicella zoster virus (VZV) may have an antigenic role in the evolution of MS, and MS remission after varicella (1) may parallel the phenomenon described by Critchfield (12). It was decided to evaluate the immunogenicity, safety and possible therapeutic effects of attenuated live VZV on 50 patients with chronic progressive MS in an open pilot study. The neurological observations have been previously reported (13). This paper reports observations of the antibody changes to the vaccine.

\section{PATIENTS AND METHODS}

The protocol was approved by the University of Manitoba, Faculty Committee on the Use of Human Subjects in Research and the Research Committee of the Health Sciences Centre in Winnipeg, Manitoba; the Food and Drug Administration in Washington, DC; and the Health Protection Branch, Health and Welfare Canada in Ottawa, Ontario.

An open pilot study was designed to test the safety and possible efficacy of varicella zoster vaccine. Investigations at entry included complete blood count, urinalysis, biochemical profile, chest x-ray, electrocardiogram and quantitative humoral varicella antibody testing by ELISA. Using the Enzygnost kit (Hoechst-Bering), anti-VZV/ immunoglobulin G (IgG) antibodies were measured at entry and at second, fourth, and final neurological examination (three, six and 14 months after entry). Magnetic resonance imaging (MRI) of the head with enhancement was performed at entry, six months and 14 months after the first examination.

Vaccine: Merck Sharp and Dohme Research Laboratories supplied $2500.7 \mathrm{~mL}$ vials of OKA/Merck Varicella Vaccine, Lot 1164/c-T684, plaque forming units unknown, and $2500.7 \mathrm{~mL}$ vials of sterile diluent, distilled water without preservatives. The vaccine was stored at $-20^{\circ} \mathrm{C}$ and the diluent was refrigerated. The vaccine was reconstituted by adding all of a vial of diluent to a vial of lyophilized vaccine and agitating the mixture thoroughly. Then $0.5 \mathrm{~mL}$ of the mixture was injected subcutaneously within 5 mins of reconstitution. After nine patients had been given this dose (six patients had two vaccinations and three had one only) the dose was doubled, ie, two vials were reconstituted for each injection and $0.5 \mathrm{~mL}$ from each (total dose $1.0 \mathrm{~mL}$ ) was used for each vaccination. A trained experienced nurse gave all vaccinations. 
TABLE 1

Details of the cohort $(n=50)$

\begin{tabular}{lr}
\hline & N \\
\hline Age (years) & \\
$20-29$ & 1 \\
$30-39$ & 17 \\
$40-49$ & 21 \\
$50-59$ & 11 \\
Disease duration (years) & \\
$0-9$ & 17 \\
10-19 & 21 \\
$20-29$ & 8 \\
$>30$ & 4 \\
Expanded disability status scale at entry & \\
$2.0-3.5$ & 12 \\
$4.0-6.0$ & 12 \\
$6.5-7.0$ & 8 \\
$7.5-8.0$ & 17 \\
8.5 & 1 \\
\hline
\end{tabular}

The first vaccine was given after the initial laboratory, clinical and MRI examinations were completed. The second vaccination was given six weeks later.

At each vaccination patients were given a vaccination report card and a clinical thermometer. The report card listed all known postvaccination symptoms. For 30 days after vaccination, patients were asked to take their temperature at the same time every day, record it, note any symptoms and then return the card.

Statistical methods: Repeated measures analysis of variance were used to compare repeated assessments over time. Spearman Rank correlation coefficients evaluated associations between different variables. Exact permutation tests were used to evaluate sparse contingency tables for differences in proportions within categories. Significance levels were set at alpha equal to 0.05 .

The clinical and laboratory assessments were done at the Health Sciences Centre; and the MRI examinations at the St Boniface General Hospital in Winnipeg, Manitoba. Both are tertiary care hospitals. All antibody determinations were done by Cadham Provincial Laboratory in Winnipeg, Manitoba on all sera together at the end of the trial.

Population studied: Patients were eligible for enrolment if they had clinically definite MS $(14,15)$ and had evidence of gradual deterioration of their MS in the 18 months before the trial. Patients were accepted with chronic progressive or relapsing progressive MS, provided they had not had an acute relapse in the previous year. Patients were between 18 and 60 years of age and capable of providing informed consent. It was emphasized to all patients that injecting a live virus into a person with a damaged or possibly damaged blood-brain-barrier might be hazardous. Premenopausal women were accepted if they had a negative pregnancy test and would use contraception for the following two years. Patients who had taken azathioprine, corticosteriods or any other immune suppressing agent 30 days before entering into the trial were excluded.
TABLE 2

Mean absorbance value \pm SD of varicella antibodies (ELISA)*

\begin{tabular}{cccc}
\hline \multicolumn{3}{c}{ Postvaccination } \\
Entry & $\mathbf{3}$ months $^{+}$ & $\mathbf{6}$ months & $\mathbf{1 4}$ months \\
\hline $1.284 \pm 0.551$ & $1.662 \pm 0.477^{\ddagger}$ & $1.598 \pm 0.478^{\ddagger}$ & $1.440 \pm 0.481^{\ddagger}$ \\
\hline${ }^{*}$ Antibody levels are expressed as optical density absorbent values. ${ }^{\dagger} \mathrm{Sec}-$ \\
ond vaccination given at this time. ${ }^{\ddagger} P=0.001$ from entry level. The rise cor- \\
related inversely with the level at entry; $r=0.70 P=0.0001$
\end{tabular}

Patients were excluded if they had ever received cyclophosphamide or mediastinal radiation. All patients had an Expanded Disability Status Scale (16) of 2.0 or greater at entry and were free of any other major disease. All agreed to take no new medication apart from analgesics (excluding acetylsalicylic acid) during the trial. The first 50 consecutive patients meeting these qualifications were included.

Vaccination: Forty-seven patients were vaccinated twice. Two of these did not complete the trial. Three were vaccinated once and withdrew. These five were followed for one year and reported no untoward effects related to the vaccine.

Sixty-one vaccinations were uneventful. Thirty-two vaccinations were followed by pain, tenderness, swelling and/or redness at the injection site for two to three days after the first or second or both vaccinations. Two patients had elevated temperatures of 1 to $1.5^{\circ} \mathrm{C}$ with the local symptoms.

Generalized muscle aching and stiffness for four to six days followed two vaccinations. Photophobia, headache, stiff neck and coryza-like symptoms followed four vaccinations.

Four patients developed minor episodes of probable varicella three to six days after vaccination. Two of these were not seen but described itchy patches of vesicles on limbs and trunk, probably less than 20 vesicles in all and no constitutional symptoms. The other two cases were seen. One had 25 vesicles on limbs and abdomen and felt generally unwell. The vesicles were clinically consistent with varicella, but culture was negative. The fourth patient had about 20 to 25 grouped vesicles on a red base on the back, buttocks, shoulder and thigh. Temperature was normal, the lesions were not itchy, and there were no constitutional signs or symptoms. Again, culture of vesicle fluid was negative.

\section{RESULTS}

Enrolment began in March 1992 and ended in October 1992. The last patient completed the study December 1993, and the average period of observation was 14 months.

The cohort demographics are shown in Table 1 . Fifty subjects entered the study and 45 completed it. The five who were lost failed to appear for subsequent clinical assessments $(n=2)$, could not tolerate the MRI examinations $(n=1)$ or quit the trial of their own volition $(n=2)$. There were 10 males. The changes in clinical findings and MRI have been reported elsewhere (13). Fourteen of 45 patients improved clinically and all of these had improvement in MRI findings. As there were no controls, this result was difficult to interpret. Twenty-nine had no change in their clinical condition. Many of these had no MRI indication of activity or progression of MS at any time in the study. Four patients worsened. The safety of the attenu- 
ated virus in this disease is established and a controlled trial of frequent, high dose VZV antigen can go ahead, using only patients with active MS as shown by repeated preliminary MRI assessments.

The presence of IgG against varicella was measured by the ELISA method on all patients at 0 , three, six, and 14 months after the first vaccination. There were no relationships between the antibody level measured at entry and the patient's age, duration of disease or level of disability. The antibody levels are shown in Table 2. All patients were seropositive on entry and all had a significant rise in antibodies following vaccination (Table 2). The rise persisted for seven to 14 months and was inversely proportional to the antibody level at entry. The patients who received smaller doses of vaccine had no significant difference in their antibody responses compared with those receiving large doses.

\section{DISCUSSION}

The two original MS patients with adult varicella are a clinical observation and there is little more to say about them. Both had varicella consistent with Heberden's description (17) and both had clinically definite MS by the standards of the day. Both had chicken pox as children.

No one was injured by the vaccine. There was better than $95 \%$ compliance by the patients in completing their postvaccination report cards.

It has been reported by others that this vaccine produces substantial antibody increases in seropositive adults as well as boosting cellular immunity and is safe (18).

There is controversial evidence of an increased incidence of

\section{REFERENCES}

1. Ross RT. Varicella and remission of multiple sclerosis. Lancet 1991;337:300. (Lett)

2. Kurtzke JF, Beebe GW, Norman JE. Epidemiology of multiple sclerosis in US veterans: 1 . Race, sex, and geographic distribution. Neurology 1979;29:1228-35.

3. Ross RT, Cheang M. Geographic similarities between varicella and multiple sclerosis. An hypothesis on the environmental factor of multiple sclerosis. J Clin Epidemiology 1995;48:731-7.

4. Sinha DP. Chickenpox - a disease predominantly affecting adults in rural West Bengal, India. Int J Epidemiol 1976;5:367-74.

5. Kuriowa Y, Igata A, Itahara K, et al. Nationwide survey of multiple sclerosis in Japan. Neurology 1975;25:845-51.

6. Takahashi M. Herpes: varicella-zoster virus. In: Lennette EG, Halonen P, Murphy FA, eds. Laboratory Diagnosis of Infectious Diseases: Principles, Vol II Viral, Rickettsial and Chlamydial Disease. New York: Springer Verlag, 1988:261-83.

7. Ross RT, Nicolle LE, Cheang M. Varicella zoster virus and multiple sclerosis in a Hutterite population. J Clin Epidemiol 1995;48:1319-24.

8. Elian M, Dean G. Multiple sclerosis among the United Kingdom-born children of immigrants from the West Indies. J Neurol Neurosurg Psychiat 1987;50:327-32.

9. Dean G. Annual incidence, prevalence and mortality of multiple sclerosis in white South African born and in white immigrants to South Africa. BMJ 1967;ii:724-32.

10. Dean G, Kurtzke JF. On the risk of multiple sclerosis according to age at migration to South Africa. BMJ 1971;iii:725-9.

11. Preblud SR, D'Angelo LJ. Chickenpox in the United States 1972-1977. From the Centers for Disease Control. J Infect Dis $1979 ; 140: 257-9$. herpes zoster in MS (19-21). Ten of the 50 patients in this study had a history of herpes zoster; one had two attacks. In five patients, the zoster occurred between ages 10 and 20; in two in their mid-20s; and in the others it was at 35, 49 and 50 years of age. With continued follow-up the occurrence of zoster in these 50 patients will be reported.

Other groups of MS patients have been vaccinated with polyvalent, A and B strain influenza vaccine without a worsening of the MS $(22,23)$.

Live attenuated varicella vaccine appears to be safe when given to patients with active MS. If the VZV is antigenically active in the evolution of MS, then an MS treatment strategy comparable with the methods used by Critchfield et al (12) in experimental allergic encephalomyelitis might be developed.

ACKNOWLEDGMENTS: It is a pleasure to thank Gail Landry for coordinating the investigations, administrating the funds, and the innumerable day-to-day tasks of the trial over the two and a half year period, plus for many hours in library searches and manuscript preparation. Ruth Loewen has done exemplary work as the study nurse. She gave all vaccinations and was available to all the patients for initial responses to multiple enquiries and encouraged patients to complete and return their postvaccination records. The authors thank Drs AJ Gomori, MR Young, CN Bourque, MD Fast, FS Dominique, A Auty, N Pillay, A Nath, MJ Newman, DE Hobson, JB Rusen and RC Bright for their referrals of patients for possible inclusion in the trial. This work was supported by the Murphy Foundation, The Health Sciences Centre Research Foundation, The Manitoba Medical Service Foundation, and Merck Frosst Canada Inc.

12. Critchfield JM, Racke MK, Zuniga-Pflucker JC, et al. T-cell deletion in high antigen dose therapy of autoimmune encephalomyelitis. Science 1994;263:1139-42.

13. Ross RT, Nicolle LE, Cheang M. The varicella zoster virus: A pilot trial of a potential therapeutic agent in multiple sclerosis. J Clin Epidemiol. (In press)

14. Rose AS, Ellison GW, Myers LW, Tourtellotte WW. Criteria for the clinical diagnosis of multiple sclerosis. Neurology 1976;26:20-2.

15. Poser CM, Paty DW, Scheinberg L, et al. New diagnostic criteria for multiple sclerosis: guidelines for research protocols. Ann Neurol 1983;13:227-31.

16. Kurtzke JF. Rating neurological impairment in multiple sclerosis: An expanded disability status scale (EDSS). Neurology 1983;33:1444-52.

17. Herberden W. Commentaries on the History and Cure of Diseases. Boston: Wellys and Lilly, 1818:361.

18. Arbeter AM, Starr SE, Plotkin SA. Varicella vaccine studies in healthy children and adults. Pediatrics 1986;78(Suppl 1):748-56.

19. Lenman JAR, Peters TJ. Herpes zoster and multiple sclerosis. BMJ 1969;ii:218-20.

20. Ragozzino MW, Kurland LT. Epidemiologic investigation of the association between herpes zoster and multiple sclerosis. Neurology 1983;33:648-9.

21. Martyn CN. The epidemiology of multiple sclerosis. In: Matthews WB, Compston A, Allen IV, Martyn CN, eds. McAlpine's Multiple Sclerosis. Edinburgh: Churchill Livingstone, 1991:135.

22. Bamford CR, Sibley WA, Laguna JF. Swine influenza vaccination in patients with multiple sclerosis. Arch Neurol 1978;35:242-3.

23. Sibley WA, Bamford CR, Laguna JF. Influenza vaccination in patients with multiple sclerosis. JAMA 1976;236:1965-6. 


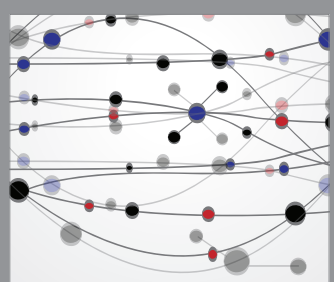

The Scientific World Journal
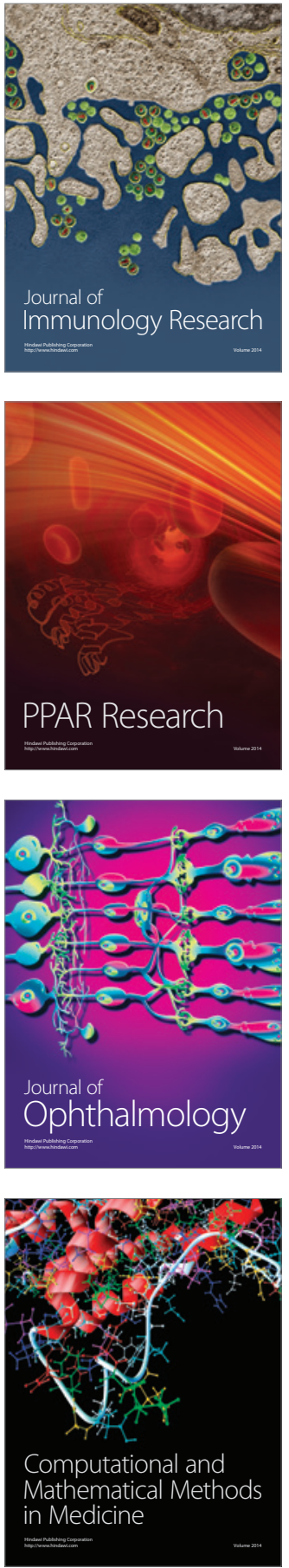

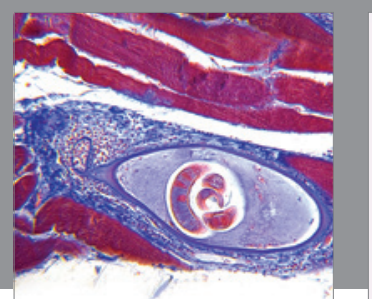

Gastroenterology Research and Practice

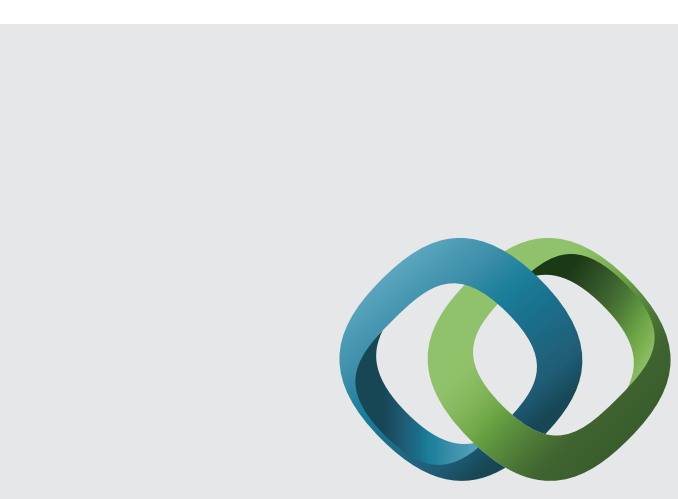

\section{Hindawi}

Submit your manuscripts at

http://www.hindawi.com
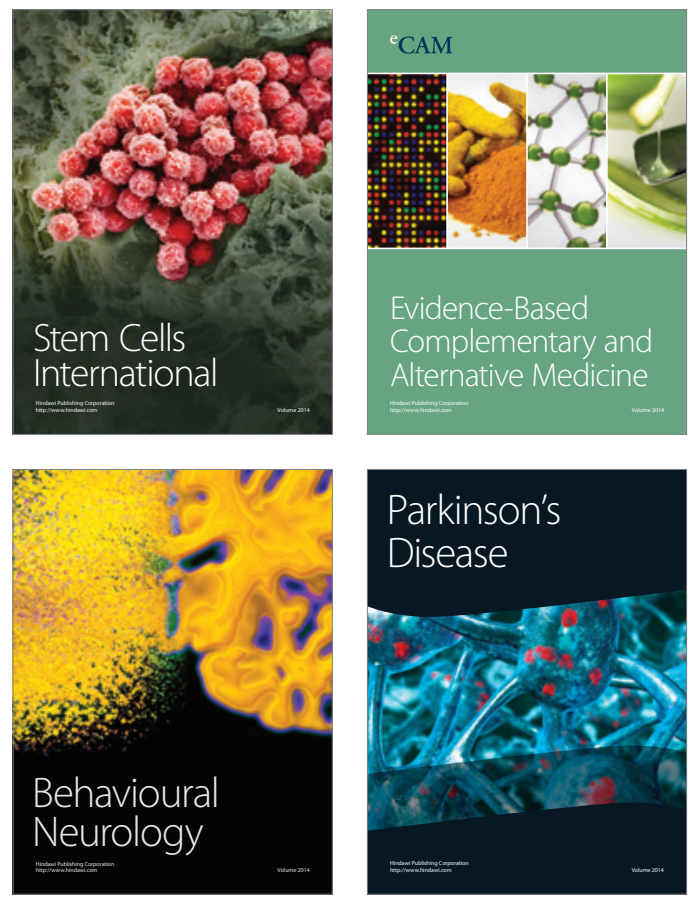
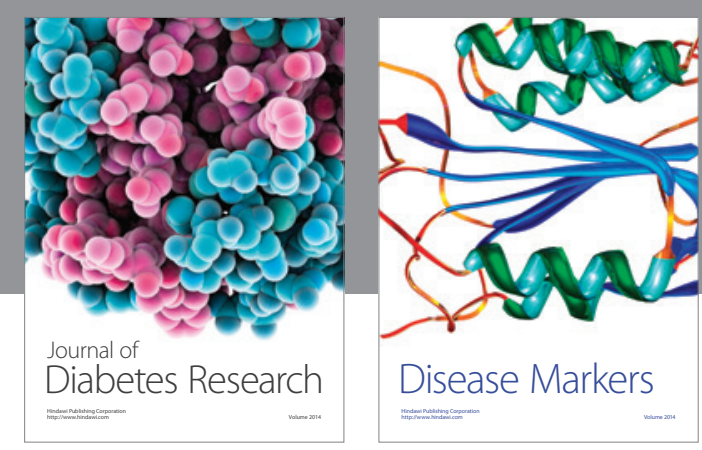

Disease Markers
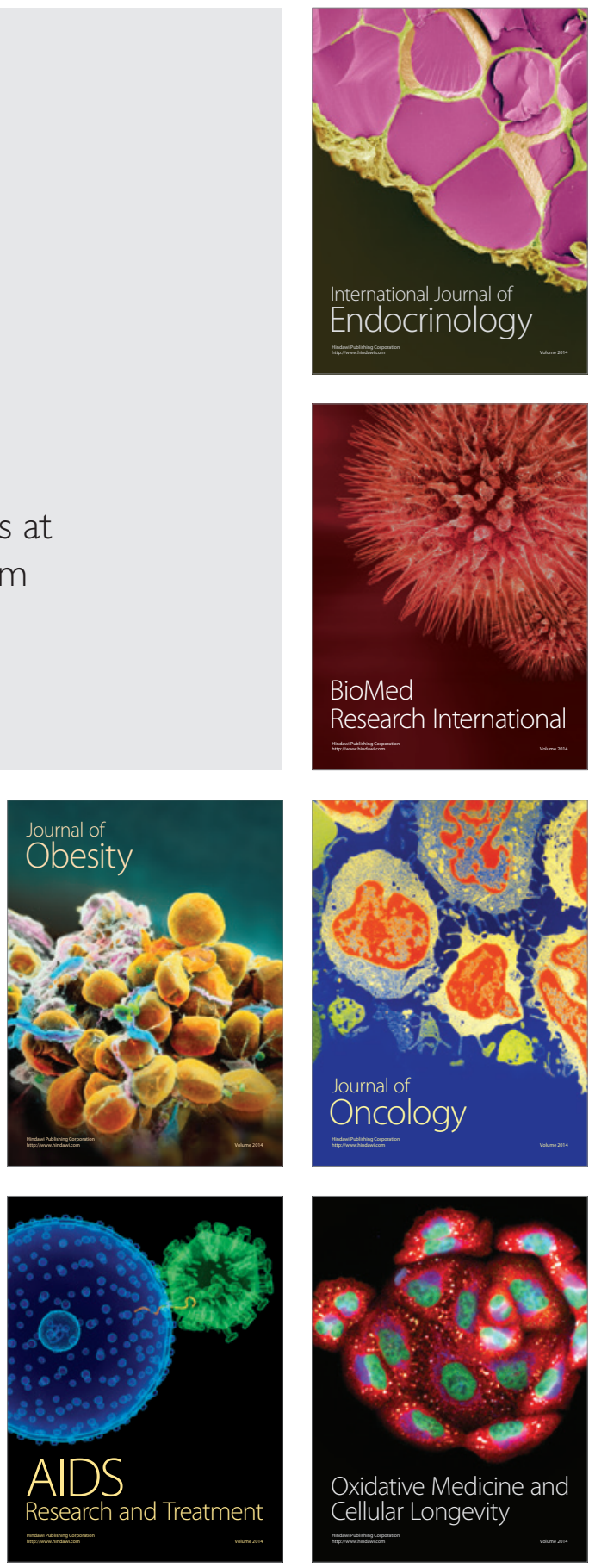